\title{
Localization of Cystic Fibrosis Transmembrane Conductance Regulator in Chloride Secretory Epithelia
}

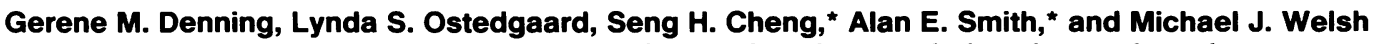 \\ Howard Hughes Medical Institute, Departments of Internal Medicine and Physiology and Biophysics, University of Iowa \\ College of Medicine, Iowa City, Iowa 52242; and *Genzyme Corporation, Framingham, Massachusetts 01701
}

\begin{abstract}
Cystic fibrosis is caused by mutations in the gene coding for the cystic fibrosis transmembrane conductance regulator (CFTR). To further our understanding of CFTR's function and regulation, we used confocal immunofluorescence microscopy to localize CFTR in cells stained with monoclonal antibodies against different regions of the protein: the $R$ (regulatory) domain (M13-1), the COOH terminus (M1-4), and a predicted extracellular domain (M6-4). All three antibodies immunoprecipitated a 155-170-kD polypeptide from cells expressing CFTR. Each antibody stained HeLa and $3 \mathrm{~T} 3$ cells expressing recombinant CFTR, but not cells lacking endogenous CFTR: HeLa, NIH-3T3, and endothelial cells. For localization studies, we used epithelial cell lines that express endogenous CFTR and have a cAMP-activated apical $\mathrm{Cl}^{-}$permeability: $\mathrm{T84}, \mathrm{CaCo}$, and HT29 clone 19A. Our results demonstrate that CFTR is an apical membrane protein in these epithelial cells because (a) staining for CFTR resembled staining for several apical membrane markers, but differed from staining for basolateral membrane proteins; (b) thin sections of cell monolayers show staining at the apical membrane; and (c) M6-4, an extracellular domain antibody, stained the apical surface of nonpermeabilized cells. Our results do not exclude the possibility that CFTR is also located beneath the apical membrane. Increasing intracellular cAMP levels did not change the apical membrane staining pattern for CFTR. Moreover, insertion of channels by vesicle fusion with the apical membrane was not required for cAMP-mediated increases in apical membrane $\mathrm{Cl}^{-}$conductance. These results indicate that CFTR is located in the apical plasma membrane of $\mathrm{Cl}^{-}$-secreting epithelia, a result consistent with the conclusion that $C K \Gamma R$ is an apical membrane chloride channel. (J. Clin. Invest. 1992. 89:339-349.) Key words: cystic fibrosis - epithelia - localization - intestine - cystic fibrosis transmembrane conductance regulator
\end{abstract}

Address correspondence to Dr. Michael J. Welsh, Howard Hughes Medical Institute, University of Iowa College of Medicine, 500 EMRB, Iowa City, IA 52242.

Received for publication 21 August 1991 and in revised form 8 October 1991 .

J. Clin. Invest.

(c) The American Society for Clinical Investigation, Inc.

$0021-9738 / 92 / 01 / 0339 / 11 \quad \$ 2.00$

Volume 89, January 1992, 339-349

\section{Introduction}

Cystic fibrosis (CF), ${ }^{1}$ the most common lethal genetic disease in Caucasians (1), is caused by mutations in the gene for the cystic fibrosis transmembrane conductance regulator (CFTR) (2-4). Early studies on the physiologic basis of the disease demonstrated that epithelia in CF patients are less permeable to $\mathrm{Cl}^{-}$. Subsequent studies showed that this reduced permeability to $\mathrm{Cl}^{-}$was due to a lack of cAMP-regulated $\mathrm{Cl}^{-}$channels in the apical membrane of secretory epithelia (5). Recent studies indicate that CFTR itself is a cAMP-regulated $\mathrm{Cl}^{-}$channel (6-8) that is expressed primarily in epithelia (2), results that directly link mutations in CFTR to reduced $\mathrm{Cl}^{-}$permeability in $\mathrm{CF}$ epithelia. For CFTR chloride channels to govern transepithelial $\mathrm{Cl}^{-}$secretion, they must be located in the apical membrane. We used confocal immunofluorescence microscopy to test the hypothesis that CFTR is located in the apical membrane of $\mathrm{Cl}^{-}$-secreting epithelial cells.

\section{Methods}

Materials. L- $\left[{ }^{35} \mathrm{~S}\right]$ methionine $(1,000 \mathrm{Ci} / \mathrm{mmol})$, fish gelatin, normal goat serum, and FITC-conjugated streptavidin were obtained from Amersham Corp. (Arlington Heights, IL). Biotinylated secondary antibodies were purchased from Vector Laboratories, Inc. (Burlingame, CA) or Amersham Corp. FITC-conjugated wheat germ agglutinin and [6-((6-((biotinoyl)amino)hexanoyl)amino) hexanoic acid, succinimidyl ester] (biotin-XX) were purchased from Molecular Probes, Inc. (Eugene, OR). Rabbit anti-human placental alkaline phosphatase and FITC-conjugated rabbit anti-goat IgG were obtained from Cappel (a division of Organon Teknika, Durham, NC). Forskolin, 3-isobutyl-1methyl xanthine (IBMX), and all other reagent grade chemicals were purchased from Sigma Chemical Co. (St. Louis, MO).

Cell culture. Culture conditions for HeLa (6), 3T3 (8), T84 (9), $\mathrm{CaCo} 2$ (10), and HT29 clone 19A cells (11) have been previously described. For immunoprecipitation experiments, cells were seeded on 150 -mm dishes at $5 \times 10^{4} \mathrm{cells} / \mathrm{cm}^{2}$. For immunofluorescence staining, HeLa cells were seeded on 8-well chamber slides (Lab-Tek culture slides; Nunc Inc., Naperville, IL) at $4 \times 10^{4}$ cells/well. For confocal microscopy, cells were seeded on Millicell-HA filters $(12 \mathrm{~mm}, 0.45 \mu \mathrm{m}$; Millipore Corp., Bedford, MA) at $3 \times 10^{4}$ cells/Millicell; T84 cells were grown for 14-21 d, because our signal increased up to $14 \mathrm{~d}$. HT29 and

1. Abbreviations used in this paper: biotin-XX, [6-((6-((biotinoyl)amino)hexanoyl)amino) hexanoic acid, succinimidyl ester]; $C F$, cystic fibrosis; CFTR, cystic fibrosis transmembrane conductance regulator; GS, normal goat serum; IBMX, 3-isobutyl-1-methyl xanthine; PAG, PBS supplemented with $1 \%$ BSA and $0.1 \%$ fish gelatin; R domain, regulatory domain. 
$\mathrm{CaCo} 2$ cells gave the highest signal at $8-10 \mathrm{~d}$ of culture. For the three intestinal epithelial cell lines, we measured transepithelial resistance using an Evom epithelial voltohmmeter (World Precision Instruments, Sarasota, FL) to ensure the presence of intact tight junctions. We used only monolayers with resistances $\geq 200 \Omega \cdot \mathrm{cm}^{2}$.

Expression of CFTR in HeLa cells. CFTR was expressed using the vaccinia virus/T7 hybrid expression system (12) as previously reported (3). Cultures were transfected with either the parent (control) plasmid or plasmid that contained the coding sequence for CFTR.

Monoclonal antibodies. The development of MAb M13-1, made to a $\beta$-galactosidase fusion protein from the $\mathrm{R}$ (regulatory) domain ( $\beta$-galactosidase-exon 13), has been previously described (13). Mouse monoclonal antibodies were also raised against unique peptide sequences of CFTR: M6-4 against amino acids 107-118 (peptide 6), the first predicted external loop spanning sequence, and M1-4 against amino acids 1466-1480 (peptide 1), the $\mathrm{COOH}$ terminus of the protein. Both peptides were synthesized and coupled to keyhole limpet hemocyanin by Alberta Peptide Institute (University of Alberta, Edmonton, Alberta, Canada).

Immunoprecipitation of CFTR. For immunoprecipitation of CFTR expressed in HeLa cells, cells were labeled with $\left[{ }^{35}\right.$ S $]$ methionine $(100 \mu \mathrm{Ci} / 150 \mathrm{~mm}$ plate for $1 \mathrm{~h}) 8-10 \mathrm{~h}$ after transfection. Cells were then lysed and the protein was solubilized at $4^{\circ} \mathrm{C}$ in lysis buffer $(50 \mathrm{mM}$ Tris- $\mathrm{HCl}, \mathrm{pH} 7.5,150 \mathrm{mM} \mathrm{NaCl}$, aprotinin $[1 \mu \mathrm{g} / \mathrm{ml}]$, and PMSF [1 $\mathrm{mM}$ ) containing $1 \%$ recrystallized digitonin. Cell lysates were immunoprecipitated with MAb (M13-1, $0.35 \mu \mathrm{g}$; M1-4 and M6-4, $10 \mu \mathrm{g}$ in $0.25-0.5 \mathrm{ml}$ ) for $2 \mathrm{~h}$. Antibody-antigen complexes were precipitated with rabbit anti-mouse IgG (Cappel) and protein A-Sepharose (Pierce Chemical Co., Rockford, IL) and washed three times with lysis buffer with detergent and once with lysis buffer alone. Sample buffer $(17 \%$ glycerol, 3.4\% SDS, $66.9 \mu \mathrm{M}$ DTT, $0.125 \mathrm{M}$ Tris- $\mathrm{HCl}, \mathrm{pH} 6.8$, and $0.008 \%$ bromophenol blue) was added to the washed precipitates and samples were incubated at room temperature for 5-10 min. Proteins were electrophoresed on $8 \%$ SDS polyacrylamide gels (SDS-PAGE), stained, destained, treated with EN $^{3}$ HANCE (Amersham Corp.), and vacuum-dried before exposure to $x$-ray film. Using the same conditions, CFTR was immunoprecipitated from unlabeled 3T3 cells that were stably transfected with the coding sequence for CFTR (3T3CFTR; Genzyme Corp., Framingham, MA) and the immunoprecipitated proteins were phosphorylated in vitro $\left(30 \mathrm{~min}, 30^{\circ} \mathrm{C}\right)$ using catalytic subunit of cAMP-dependent protein kinase $(20 \mathrm{ng})$ (Promega Corp., Madison, WI) and $10 \mu \mathrm{Ci}\left[{ }^{32} \mathrm{P} \gamma\right] \mathrm{ATP}$ (New England Nuclear, Boston, MA) in $50 \mathrm{mM}$ Tris- $\mathrm{HCl}, \mathrm{pH} 6.8,10 \mathrm{mM} \mathrm{MgCl}_{2}$, and 0.1 $\mathrm{mg} / \mathrm{ml} \mathrm{BSA}$.

Immunofluorescence staining. All solutions were filtered through $0.22-\mu \mathrm{m}$ filters (Gelman Sciences Inc., Ann Arbor, MI) and incubations were done at room temperature unless indicated otherwise. $12 \mathrm{~h}$ after transfection, HeLa cells were washed twice with PBS (120 mM

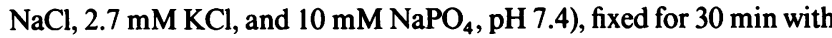
$3.7 \%$ formaldehyde, and permeabilized for 20 min with $0.05 \%$ NP-40 (Pierce Chemical Co.). Residual aldehydes were inactivated by incubating for $30 \mathrm{~min}$ with PBS containing $50 \mathrm{mM}$ glycine. Cells were blocked for $1 \mathrm{~h}$ with $10 \%$ normal goat serum (PBS/GS), incubated $2 \mathrm{~h}$ with primary antibody (diluted 1:2-1:20 in PBS/GS), and washed three times for 10 min each. Cells were then incubated for $1 \mathrm{~h}$ with FITCconjugated goat anti-mouse IgG (Cappel) (1:200 in PBS/GS) and washed as described above. Mounting medium (Gelmount; Biomeda Corp., Foster City, CA) and a glass coverslip was placed on the cells. Immunofluorescence staining was observed using an inverted microscope (Carl Zeiss, Inc., Thornwood, NY).

Before staining epithelial cells grown on permeable filter supports, we removed the mucus layer by incubating the cells for $40 \mathrm{~min}$ at $37^{\circ} \mathrm{C}$ with $5 \mathrm{mM}$ DTT and $0.2 \mathrm{U} / \mathrm{ml}$ neuraminidase (type VIII, from Clostridium perfringens; Sigma Chemical Co.) in serum-free medium. Monolayers maintained their transepithelial resistance and response to cAMP agonists after this treatment. To determine the effect of cAMP on CFTR localization, forskolin and IBMX were added during the last $10 \mathrm{~min}$ of neuraminidase treatment and during fixation; indomethacin was present before and during stimulation to prevent increased cAMP caused by prostaglandin production. Cultures for confocal microscopy were washed twice and fixed for 30 min with $4 \%$ paraformaldehyde in PBS. After fixation, filters were cut from their support for staining. All subsequent incubations and washes were done with PBS supplemented with $1 \%$ BSA (fraction V) and $0.1 \%$ fish gelatin (PAG) at room temperaature unless otherwise indicated. Maximal permeabilization was obtained with $0.2 \%$ Triton X-100 or NP-40 for 20 min. Residual aldehydes were inactivated as described above and nonspecific binding was blocked by incubating cells for $1 \mathrm{~h}$ with 5-10\% goat serum (PAG/GS). Cells were incubated overnight at $4^{\circ} \mathrm{C}$ with primary antibody (M13-1 and M1-4, 1:10-1:20; M6-4, 1:2; and anti-alkaline phosphatase, 1:75 in PAG/GS) and washed three times for 10 min each. For controls, we used purified mouse IgG at concentrations equal to or greater than that used for immune staining. Cultures were incubated with secondary antibody (biotinylated anti-IgGs, 1:100; FITC-conjugated anti-IgGs, 1:200-1:400) for $1 \mathrm{~h}$ and washed as described above. If biotinylated secondary antibodies were used, cultures were then incubated with FITC-conjugated (1:50-1:100) streptavidin in PAG for $30 \mathrm{~min}$. Incubations with FITC-conjugated wheat germ agglutinin (1:100) were for $30 \mathrm{~min}$. After the final wash, the filters were placed on a glass slide and mounting medium and a glass coverslip were placed over the cells.

For biotinylation of membrane proteins, monolayers were treated with neuraminidase/DTT as described above. Cells were washed twice with ice-cold PBS containing $1.2 \mathrm{mM} \mathrm{CaCl}_{2}$ and $1.2 \mathrm{mM} \mathrm{MgCl}$ and incubated for $30 \mathrm{~min}$ at $4^{\circ} \mathrm{C}$ with $0.5 \mathrm{mg} / \mathrm{ml}$ biotin-XX. The filters were then washed twice with PBS, fixed, and processed as described above. To visualize the biotinylated proteins, permeabilized monolayers were incubated with fluorochrome-conjugated streptavidin for $30 \mathrm{~min}$.

For some studies monolayers on filters were prepared as described above and then embedded in paraffin and sectioned. Paraffin was removed by washing twice for $5 \mathrm{~min}$ with xylene. Sections were then rehydrated using an ethanol series $(100,90,80,70,60,50 \%)$ and rinsed twice with distilled water. Sections were washed twice for $15 \mathrm{~min}$ with PBS and stained as described above for monolayers on Millicells. Confocal images were obtained using the MRC- 600 confocal imaging system with an argon ion laser (Bio-Rad Microsciences Division, Cambridge, MA).

The study of apical $\mathrm{Cl}^{-}$channels. T84 cells were cultured on permeable supports and studied in modified Ussing chambers (Jim's Instruments, Iowa City, IA). The basolateral membrane was permeabilized with $100 \mu \mathrm{g} / \mathrm{ml}$ Staphylococcus aureus $\alpha$-toxin prepared as previously described $(15,16)$. The mucosal solution contained (millimolar): 135 $\mathrm{NaCl}, 1.2 \mathrm{MgCl}_{2}, 1.2 \mathrm{CaCl}_{2}, 2.4 \mathrm{~K}_{2} \mathrm{HPO}_{4}, 0.6 \mathrm{KH}_{2} \mathrm{PO}_{4}, 10$ Hepes ( $\mathrm{pH}$ 7.4), and 10 dextrose. ATP was added to the basolateral solution to minimize temperature-dependent changes in the metabolic production of ATP. The submucosal solution contained (millimolar): $30 \mathrm{NaCl}$, $100 \mathrm{NaGluconate,} 3 \mathrm{MgCl}_{2}, 2.4 \mathrm{~K}_{2} \mathrm{HPO}_{4}, 0.6 \mathrm{KH}_{2} \mathrm{PO}_{4}, 1$ ATP, 10 Hepes (pH 7.4), and 10 dextrose. We measured the current required to maintain transepithelial voltage at $0 \mathrm{mV}$. With these conditions $\alpha$ toxin permeabilizes the basolateral membrane to ions and nucleotides but leaves the tight junctions and apical membrane intact (14). Thus, under these conditions changes in current reflect opening of apical $\mathrm{Cl}^{-}$ channels. Temperature of the chamber solution was controlled at 3637 or $4-5^{\circ} \mathrm{C}$ with a heating and cooling circulator (Haake Instruments Inc., Saddle Brook, NJ). To open apical membrane $\mathrm{Cl}^{-}$channels by activating cAMP-dependent protein kinase, we added $10 \mu \mathrm{M}$ cAMP to the submucosal solution (note that because the basolateral membrane is permeabilized to nucleotides, it is not necessary to add a membrane permeant form of (AMP). We verified that cAMP-dependent protein kinase is active at reduced temperatures by using an in vitro assay with the synthetic peptide Kemptide (Peninsula Laboratories, Inc., Belmont, CA). Assays were carried out at either 4 or $37^{\circ} \mathrm{C}$ in $50 \mathrm{mM}$ Tris,

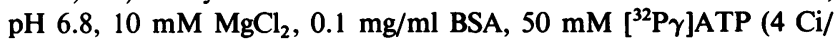
$\mathrm{mmol}$ ), and $50 \mathrm{mM}$ Kemptide. The reaction was started with the addition of $20 \mathrm{ng}$ of the catalytic subunit of protein kinase A (Promega Corp., Madison, WI) and stopped by spotting on phosphocellulose 


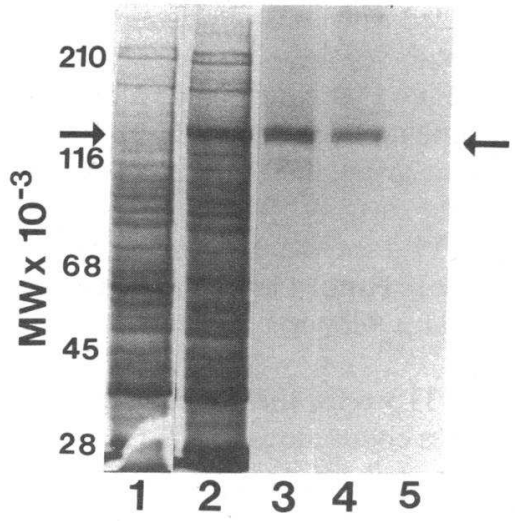
unoprecipitates from extracts containing CFTR using MAbs against the R domain (M13-1, lane 3) and the $\mathrm{COOH}$ terminus (M1-4, lane 4 ) or in the absence of primary antibody (lane 5). Arrows indicate the position of a $150-\mathrm{kD}$ polypeptide, previously identified as the core glycosylated form of CFTR.

paper. The phosphorylation of Kemptide (expressed as percentage of counts at $4^{\circ} \mathrm{C}$ relative to counts at $37^{\circ} \mathrm{C}$ ) was: $60 \mathrm{~min}, 29.4 \pm 8.29 ; 120$ $\min , 40.1 \pm 1.79$.

\section{Results and Discussion}

Determination of antibody specificity. Earlier work demonstrated that MAb M13-1 recognizes CFTR (13): M13-1 im- munoprecipitated CFTR made by in vitro translation, by in vivo production from cells transfected with plasmids encoding CFTR, and by T84 cells. The protein recognized by M13-1 was a glycosylated phosphoprotein (as predicted by the amino acid sequence of CFTR), and had the same tryptic digestion pattern irrespective of the source of CFTR.

Fig. 1 shows that M13-1 (lane 3) and M1-4 (lane 4) immunoprecipitated a unique $150-\mathrm{kD}$ polypeptide when CFTR was expressed in HeLa cells. This polypeptide is the core glycosylated form of CFTR, the major form of the protein expressed in HeLa cells under these conditions $(6,13)$. M6-4 was less efficient at immunoprecipitating CFTR and detectable amounts of the protein were only observed using the more sensitive technique of in vitro phosphorylation (see Fig. 3). All three MAbs stained only HeLa cells expressing CFTR. Fig. 2 shows staining of HeLa cells that were transfected with a CFTR-containing plasmid using the vaccinia virus/T7 hybrid expression system (Fig. 2, $a-c$ ). Staining varied in intensity and pattern from cell to cell, but the overall appearance of the staining was the same for all three antibodies. Negligible staining was observed in HeLa cells transfected with control plasmid (Fig. 2, $d-f$ ).

Evidence that these antibodies recognize CFTR was also obtained using stably transfected 3T3 cells expressing CFTR. Previous studies demonstrated that M13-1 immunoprecipitates three species of the protein. These three polypeptides were identified as the nonglycosylated (band A), core glycosylated (band B), and mature, fully glycosylated (band C) proteins (17). Fig. 3 demonstrates that M13-1 (lane 1) and M1-4 (lane 2) immunoprecipitate all three species of CFTR from 3T3-CFTR cells. M6-4 was less efficient in immunoprecipitation assays
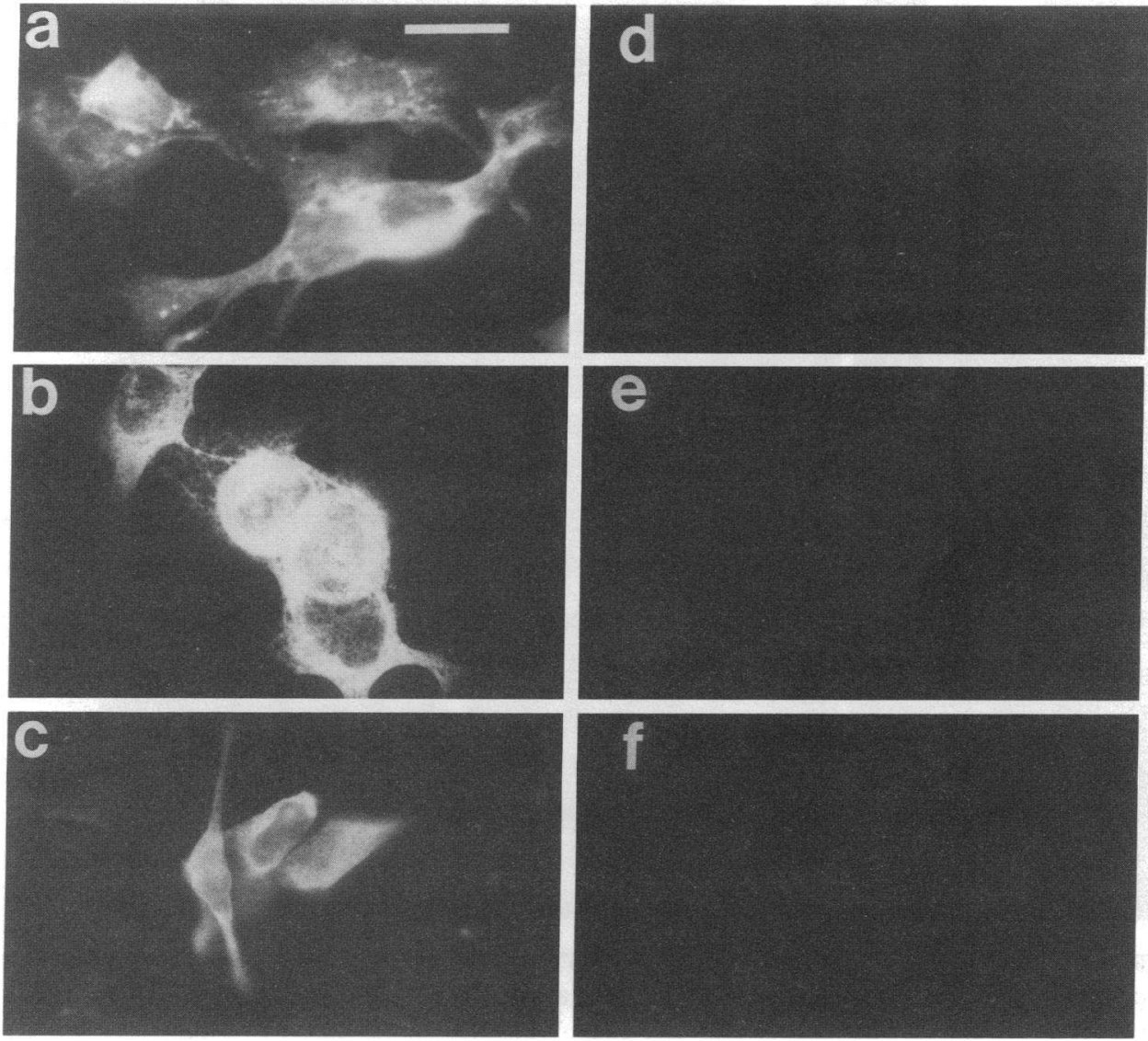

Figure 2. Antibody recognition of CFTR in immunofluorescence microscopy of transfected HeLa cells. $\mathrm{HeLa}$ cells were transfected with CFTR-containing plasmid $(a-c)$ or with control plasmid $(d-f)$ using the vaccinia virus/T7 hybrid expression system. Transfected cells were stained with MAbs M13-1 $(a, d)$, M1-4 $(b, e)$ and M6-4 $(c, f)$. Bar, 50 $\mu \mathrm{m}$. 


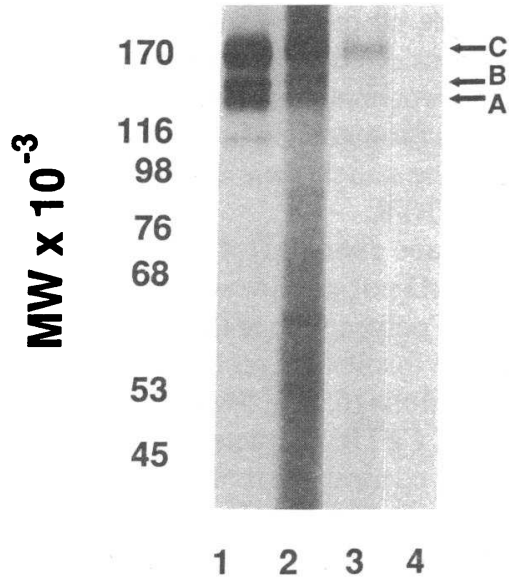

of bands A, B, and C (corresponding to nonglycosylated, core glycosylated, and fully glycosylated CFTR, respectively) are indicated.

and only fully glycosylated CFTR, the major species in these cells, was observed (lane 3). Using confocal microscopy, we observed specific staining of these cells with all three antibodies (Fig. 4, b-d) when compared with a nonimmune mouse IgG control (Fig. $4 a$ ).

In both HeLa (Fig. 2) and 3T3 cells (Fig. 4) which overexpress CFTR, staining was predominantly intracellular. As shown for HeLa cells transfected with control plasmid (Fig. 2, $d-f$ ), negligible staining was observed for nontransfected $\mathrm{HeLa}$ and NIH-3T3 fibroblasts. We have previously shown that neither HeLa nor 3T3 cells contain endogenous CFTR mRNA (by polymerase chain reaction [6]) or CFTR protein (by immunoprecipitation as described above [13]) and that they have no functional evidence of CFTR expression (i.e., they have no cAMP-activated $\mathrm{Cl}^{-}$current [6]). Human umbilical vein endothelial cells grown on permeable supports also failed to stain (not shown).

In contrast to HeLa and 3T3 cells, the epithelial cell line T84 has been shown to express endogenous CFTR (2). To obtain further evidence that our antibodies recognize CFTR, we stained monolayers of T84 cells with our antibodies and compared the observed staining intensity with that of a nonimmune mouse IgG at the same concentration. Fig. 5 demonstrates that M13-1 (Fig. $5 a$ ) increased fluorescence above background levels (Fig. $5 d$ ). Similar staining was observed with M1-4 and M6-4 (shown below). This staining was blocked by preincubation of M13-1 overnight at $4^{\circ} \mathrm{C}$ with the appropriate CFTR sequence, $\beta$-galactosidase-exon $13(0.2 \mathrm{mg} / \mathrm{ml})$ (Fig. 5 $b$ ). As a further control, M13-1 was preincubated with $\beta$-galactosidase-exon 10, a fusion protein containing CFTR sequences outside of the $\mathrm{R}$ domain; no reduction in staining intensity was observed (Fig. 5 c). In similar experiments, staining with M1-4 but not M13-1 was reduced by preincubation with keyhole limpet hemocyanin peptide $1(0.2 \mathrm{mg} / \mathrm{ml})$, and staining with
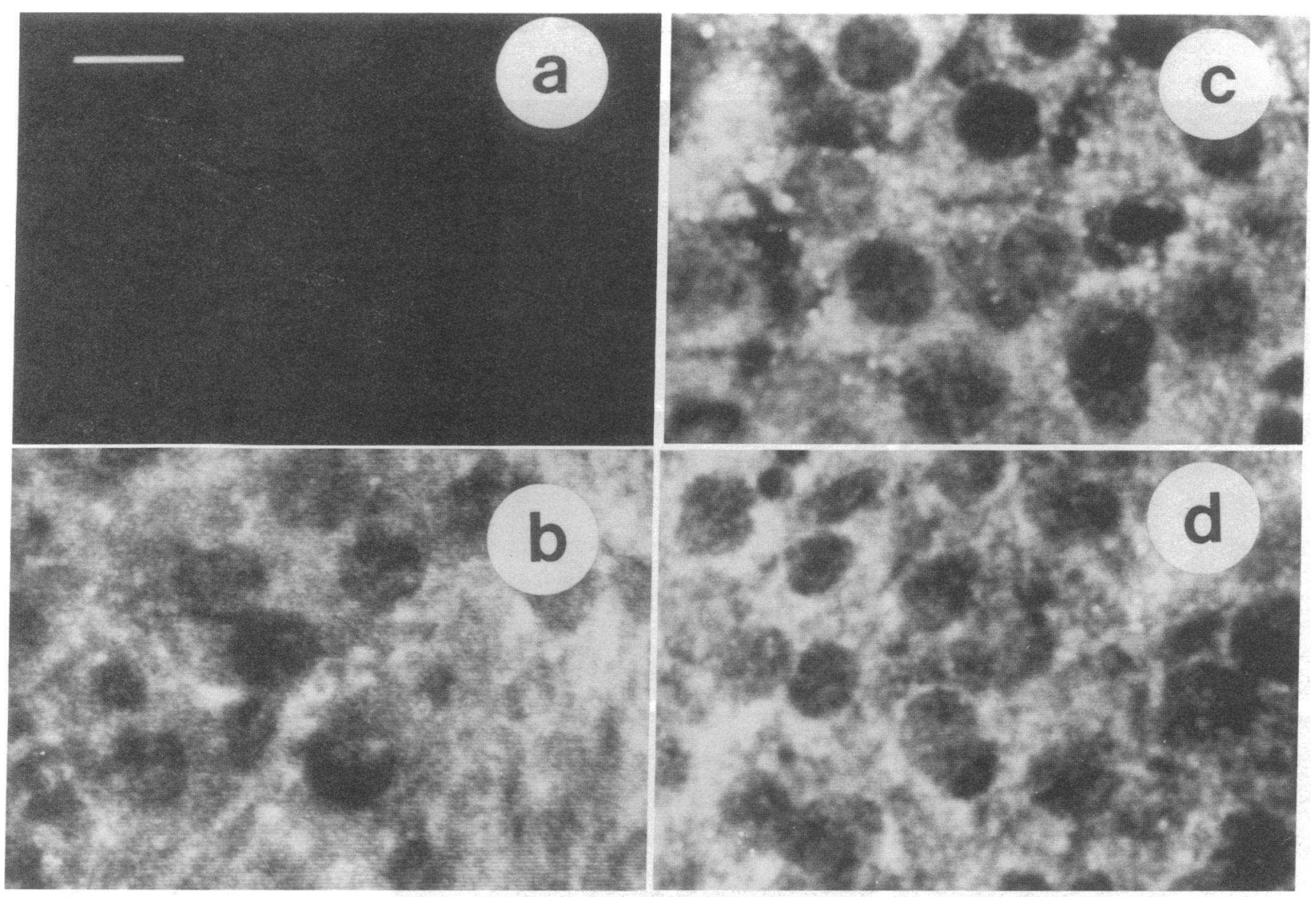

Figure 4. Antibody recognition of CFTR in confocal immunofluorescence microscopy of 3T3-CFTR cells. 3T3-CFTR cells were stained with MAbs M13-1 (b), M1-4 (c), and M6-4 (d). Images shown are a summation of images taken at different planes through the cell. $a$ shows background staining with a nonimmune mouse IgG control. Bar, $50 \mu \mathrm{m}$. 

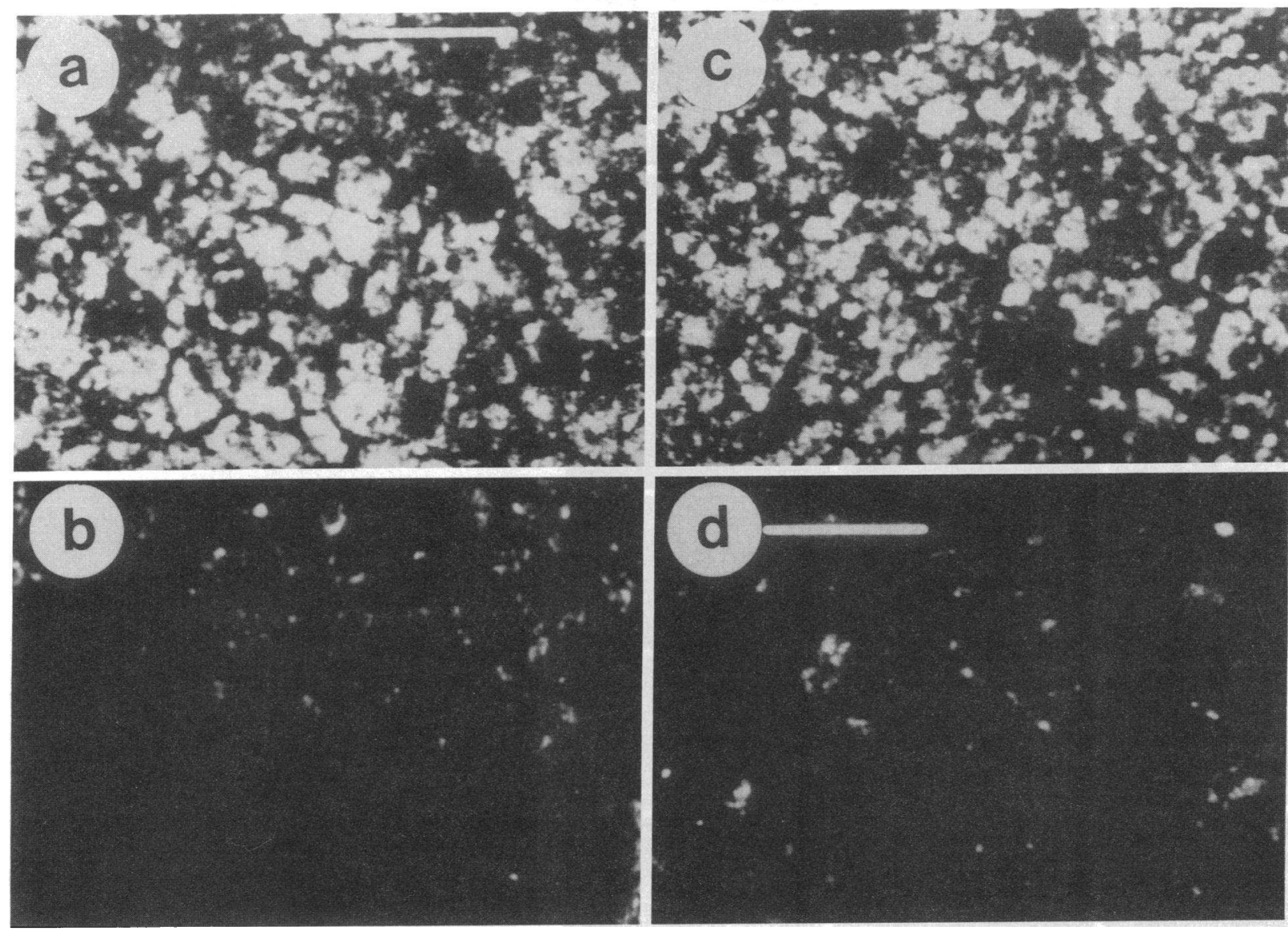

Figure 5. Antibody recognition of CFTR in T84 monolayers. T84 cells were stained with M13-1 $(a)$ or a nonimmune mouse IgG $(d)$. To test staining specificity, M13-1 was preincubated overnight at $4^{\circ} \mathrm{C}$ with a $\beta$-galactosidase fusion protein $(0.2 \mathrm{mg} / \mathrm{ml})$ containing a sequence from the $\mathrm{R}$ domain (exon 13) (b) or a CFTR sequence outside of the R domain (exon 10) (c). Bar, $25 \mu \mathrm{m}$.

M6-4 but not M13-1 was reduced by preincubation with peptide $6(0.1 \mathrm{mg} / \mathrm{ml})$ (not shown). In summary, all three antibodies stained T84 cells and this staining was specifically blocked by preincubation with the appropriate CFTR sequence, evidence that these antibodies recognize CFTR in our immunofluorescence assay.

These results and our observations shown below indicate that CFTR is recognized by antibodies made against three different epitopes: the R domain, M13-1; the $\mathrm{COOH}$ terminus, M1-4; and the first predicted extracellular domain, M6-4.

Localization of CFTR. To localize CFTR, we used three intestinal epithelial cell lines grown on permeable filter supports: T84, HT29 clone 19A, and $\mathrm{CaCo}$. Each retains the ability to polarize (i.e., to segregate apical from basolateral membrane proteins), the ability to develop a transepithelial resistance (indicating the formation of tight junctions), and the ability to secrete $\mathrm{Cl}^{-}$from the basolateral to the apical surface. Chloride secretion in each cell type is dependent upon the cAMP-regulated opening of apical membrane $\mathrm{Cl}^{-}$channels. The properties of these endogenous $\mathrm{Cl}^{-}$channels (18) are the same as those of recombinant CFTR expressed in heterologous cells (6).

We used confocal laser scanning microscopy to examine the cellular distribution of CFTR. Fig. 6 shows a series of images taken parallel to the surface of the epithelial monolayer. The first image $(1, a-c)$ was obtained above the surface of the cells; subsequent images (2-7) were obtained at $2-\mu \mathrm{m}$ steps as the microscope was focused down into the cell monolayer toward the filter support. Fig. $6 a$ shows the staining pattern observed with MAb M1-4. To compare the staining pattern of CFTR to that of apical and basolateral membrane proteins, we biotinylated either membrane and then bound FITC-conjugated streptavidin to the biotinylated membrane proteins. Fig. $6 b$ shows the resultant pattern obtained for apical membrane proteins, and Fig. $6 c$ shows the pattern obtained for basolateral membrane proteins.

Staining for apical membrane proteins has several characteristics. Staining first appears as a diffuse pattern at the surface of the cell $(b 2)$. As one steps a few micrometers down into the epithelial monolayer, an outline of the apical membrane is often observed ( $b 3$ and $b 4$ ). 6-8 $\mu \mathrm{m}$ into the cell ( $b 5$ and $b 6$ ), below the tight junctions, only background levels of fluorescence (similar to the nonimmune control) are observed.

In contrast, for biotinylated basolateral membrane proteins, the first staining observed is an outline of the cell ( $c 3$ and $c 4)$. This outline represents staining of membrane-associated proteins below the tight junctions. Although the fluorescent staining of the apical membrane extended for only a few micrometers, basolateral membrane staining often extended for $15-25 \mu \mathrm{m}$ before we reached the permeable filter support. In support of these observations, staining with an antibody against keratin and thin sections of monolayers (see Fig. 9) indicated that these epithelial cells were 15-35 $\mu \mathrm{m}$ tall.

The staining pattern observed for CFTR (Fig. $6 a$ ) included 

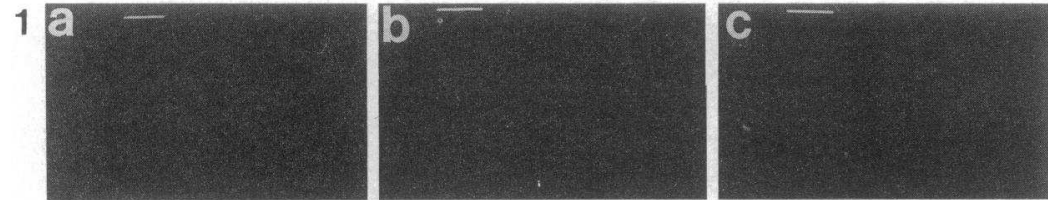

2
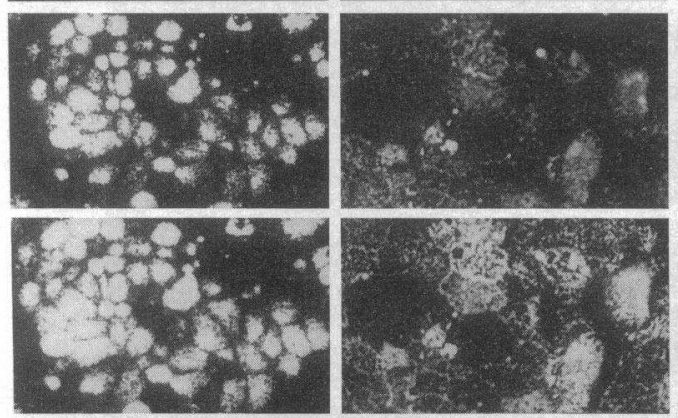

4
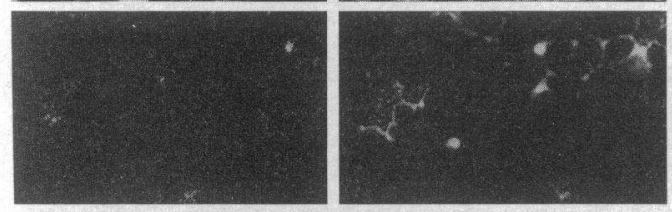

5
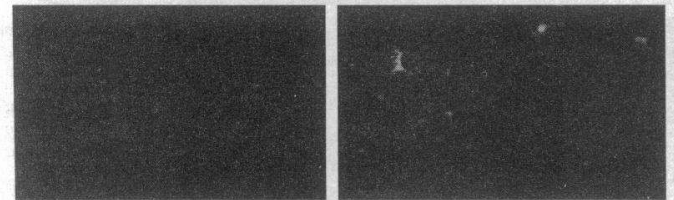

6
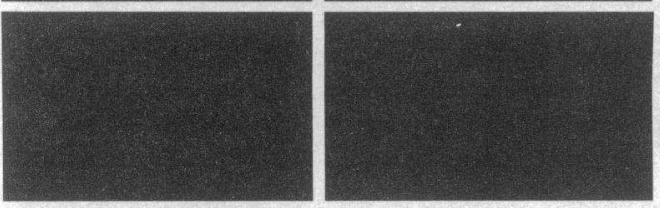

7

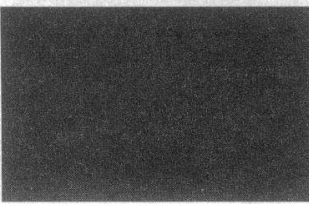

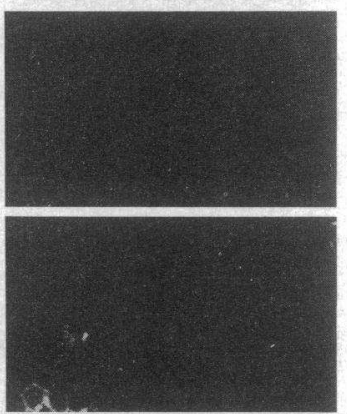
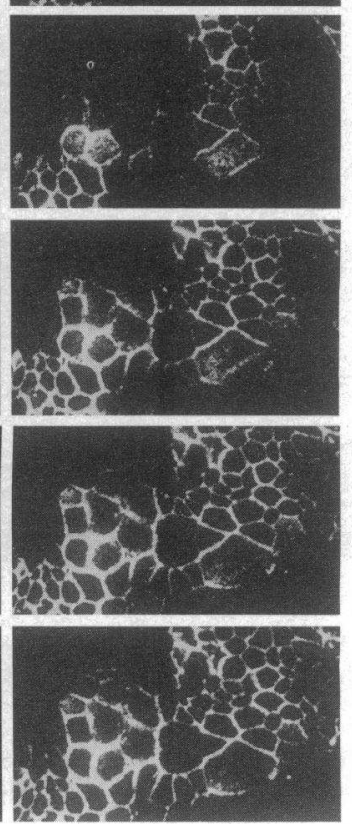

Figure 6. Comparison of the immunofluorescence staining pattern for CFTR with the patterns for apical and basolateral membrane proteins in polarized monolayers of T84 cells. A series of confocal images were collected starting above the cell monolayer and moving toward the filter support in $2-\mu \mathrm{m}$ increments. Cells were stained with M1-4 (al-7), an antibody against the $\mathrm{COOH}$ terminus of CFTR, or with FITCconjugated streptavidin after membrane-specific biotinylation of the apical $(b 1-7)$ or basolateral $(c 1-7)$ surface of the cells. Bars, $10 \mu \mathrm{m}$. an initial diffuse surface labeling ( $a 2$ and $a 3)$ followed by cell outlines (a4), similar to the ones observed with apical membrane proteins as one sections through the dome of the apical membrane. Staining in these cells is away from the nucleus, which cross-sections have shown to be located nearer the basal surface of the cells. As with apical membrane proteins, staining extended only a few micrometers into the cell.

The patterns shown in Fig. 6 demonstrate two points. First, the distribution of apical and basolateral proteins can easily be distinguished by the staining pattern. And second, the staining pattern for CFTR is similar to that for apical membrane proteins and different from that for basolateral membrane proteins.

Fig. 7 shows similar images from T84 cell monolayers (3$\mu$ m steps) obtained with antibodies M13-1 (Fig. $7 a$ ) and M6-4 (Fig. 7 b), and for comparison, two apical membrane markers, alkaline phosphatase (Fig. $7 c$ ) and wheat germ agglutinin (Fig. $7 d$ ). Although the intensity of staining varied with each antibody and from experiment to experiment, the staining pattern for CFTR was the same with all three antibodies (Figs. $6 a$ and 7, $a$ and $b$ ). More importantly, this pattern resembled that of other apical membrane proteins (Figs. $6 b$ and $7 c$ ) and glyco- proteins (Fig. $7 d$ ) but clearly differed from that of basolateral membrane proteins (Fig. $6 c$ ).

HT29 clone 19A (Fig. 8 a) and $\mathrm{CaCo} 2$ (Fig. 8 b) cells stained with M13-1 or M1-4 (not shown) had a fluorescence pattern similar to that of T84 cells: a characteristic diffuse staining of the apical surface. Although the morphology of the three epithelial cell types was different, the antibody staining localized to the apical membrane in each.

Localization to the apical surface was also observed in paraffin sections of T84 monolayers (Fig. 9) stained with M1-4. Taken together, these results demonstrate that CFTR is predominantly located either in or very near the apical plasma membrane of these secretory epithelial cells.

Demonstration that CFTR is in the apical membrane. Because the experiments presented above were done in permeabilized cells, they do not distinguish between CFTR that is located in the apical membrane and CFTR that is located in a vesicular pool just beneath the apical membrane. This distinction is important for understanding the function and regulation of CFTR. Localization in the plasma membrane would support a proposed mechanism whereby cAMP regulates $\mathrm{Cl}^{-}$ permeability by activating chloride channels already present in 

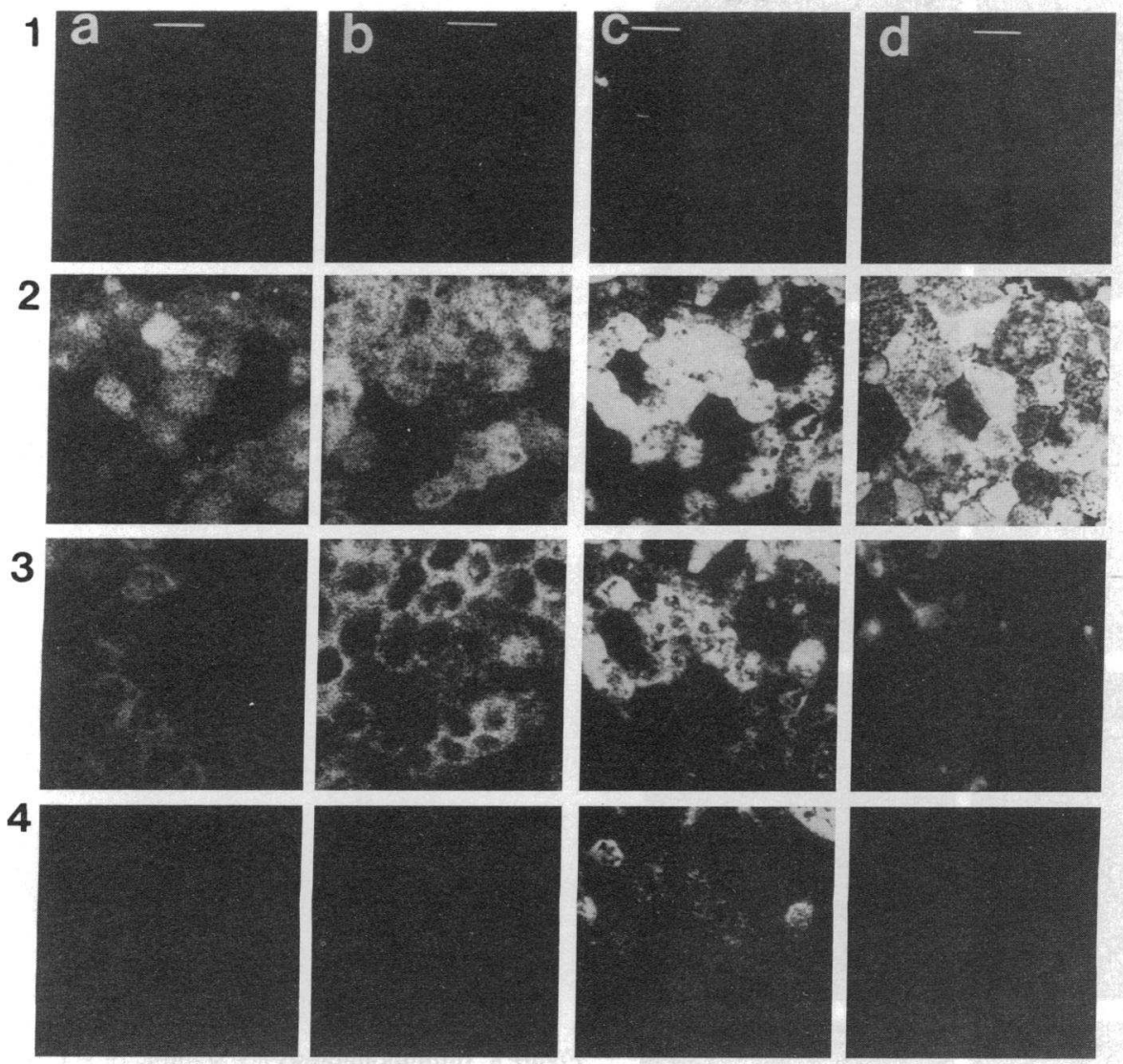

Figure 7. Comparison of the staining pattern for CFTR with other apical membrane markers in polarized monolayers of T84 cells. A series of confocal images (3- $\mu \mathrm{m}$ increments) were collected as described in Fig. 6 for monolayers that were stained with MAbs against two different domains of CFTR, M13-1 (R domain) (al-4), and M6-4 (extracellular loop) (b1-4). For comparison, the staining patterns for the apical membrane markers alkaline phosphatase $(c 1-4)$ and wheat germ agglutinin (dl-4) are shown. Bars, $10 \mu \mathrm{m}$. the apical membrane. On the other hand, localization of CFTR in vesicles beneath the plasma membrane would support a mechanism whereby cAMP regulates $\mathrm{Cl}^{-}$permeability by stimulating fusion of submembraneous vesicles with the apical membrane. Such an insertion mechanism has been proposed to deliver $\mathrm{Cl}^{-}$channels to the membrane, where they could provide a pathway for $\mathrm{Cl}^{-}$exit (19). In this regard, regulation of ion permeability via channel insertion has been observed in other epithelia (20), and cAMP has been observed to regulate the anion permeability of intracellular vesicles prepared from renal epithelia (21). Because M6-4 was raised to a predicted extracellular domain, we used it to distinguish between these two mechanisms.

We examined immunofluorescence staining of permeabilized and nonpermeabilized T84 cells with each of the three antibodies. Control experiments with antibodies against keratin were done to verify that cells were not permeabilized in the absence of detergent. Fig. 10 shows that M13-1 (Fig. 10, $b$ and $e$ ) and M1-4 (Fig. 10, $c$ and $f$ ) stained only permeabilized monolayers, as predicted for antibodies against putative cytoplasmic domains. The absence of staining by M13-1 and M1-4 in nonpermeabilized cells is not due to the fact that detergent is required to expose the antibody epitopes, because 3T3-CFTR cells on glass coverslips are permeabilized by fixation alone and showed patches of staining with all three antibodies in the absence of detergent. In contrast to our other antibodies, M6-4 stained nonpermeabilized as well as permeabilized monolayers (Fig. 10, $a$ and $d$ ). Thus, M6-4 recognized CFTR that was already in the apical membrane.

We also examined the effect of stimulating the monolayers by increasing cellular levels of cAMP. Fig. 11 shows that in- creases in cAMP did not change the staining pattern or intensity with M6-4 (Fig. 11, $a$ and $c$ ) in nonpermeabilized monolayers or of M13-1 (Fig. 11, $b$ and $d$ ) in permeabilized monolayers. Although changes below our level of detection may have occurred, our observations suggest that cAMP does not significantly alter the distribution of CFTR in these cells. If cAMP stimulated $\mathrm{Cl}^{-}$secretion via a vesicle fusion mechanism, we would expect forskolin to cause a significant increase in staining intensity using our extracellular domain antibody with nonpermeabilized cells. Because no apparent change was observed, it seems unlikely that channel insertion is the major means of regulation.

Although the data indicate that the largest pool of CFTR is in the apical membrane, they do not rule out a smaller intracellular or basolateral membrane pool. In fact, some of the protein must be present in intracellular vesicles as it is synthesized and transported to the membrane. Moreover, our data do not exclude the possibility that some CFTR is inserted into the membrane with cAMP stimulation, nor do they exclude the possibility that the function of CFTR may in some way influence vesicle trafficking. Electron microscopy could be used to examine the ultrastructural distribution and movement of CFTR. However, despite numerous attempts we were unable to detect CFTR using electron microscopy, probably because the protein is present in such low abundance.

Evidence that vesicle fusion is not required for $\mathrm{Cl}^{-}$channel activation. Our results indicate that CFTR is located in the apical membrane of secretory intestinal epithelial cells and suggest that cAMP does not stimulate insertion of the CFTR $\mathrm{Cl}^{-}$ channels into the cell membrane. To test this hypothesis we examined the effect of temperature on cAMP-regulated apical 


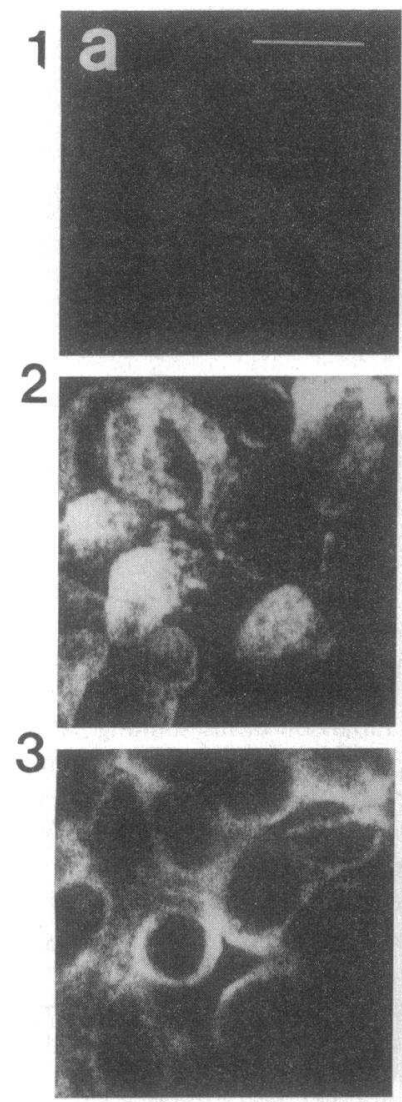

4

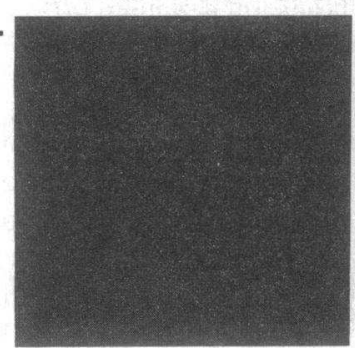

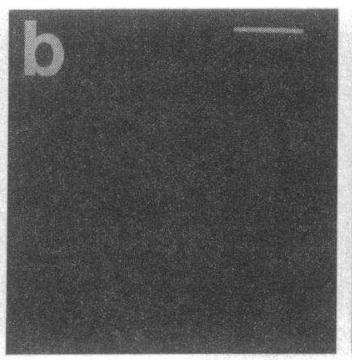
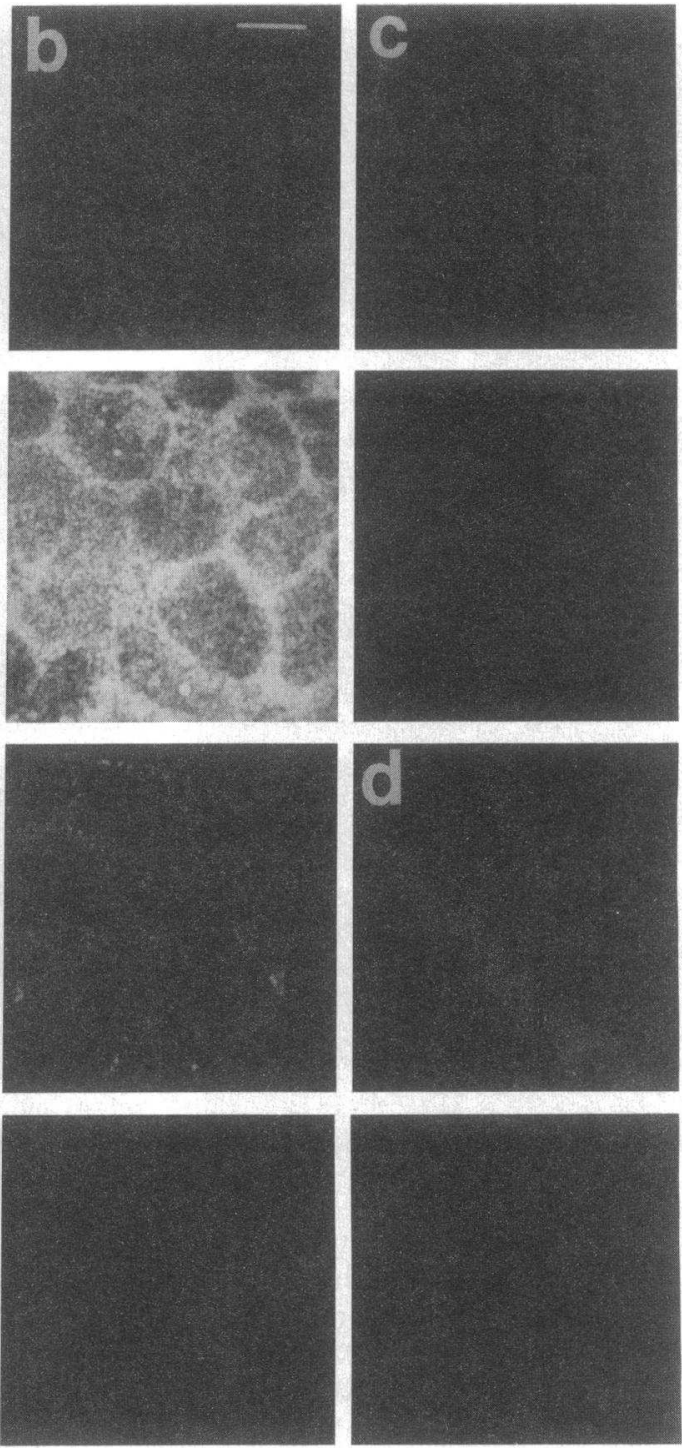

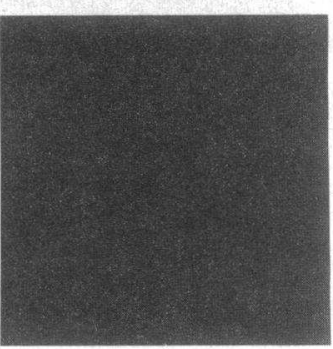

Figure 8. Immunofluorescence staining of HT29 clone $19 \mathrm{~A}$ and $\mathrm{CaCo} 2$ cells with antibodies against CFTR. A series of confocal images (3- $\mu \mathrm{m}$ increments) were collected as described in Fig. 6 for polarized monolayers of HT29 (al-4) and $\mathrm{CaCo} 2(b 1-4)$ cells that were stained with MAb M13-1. Images of nonimmune IgG controls (3$\mu \mathrm{m}$ increments) are shown for HT29 (c) and $\mathrm{CaCo} 2(d)$ cells, respectively. Bars, $10 \mu \mathrm{m}$.

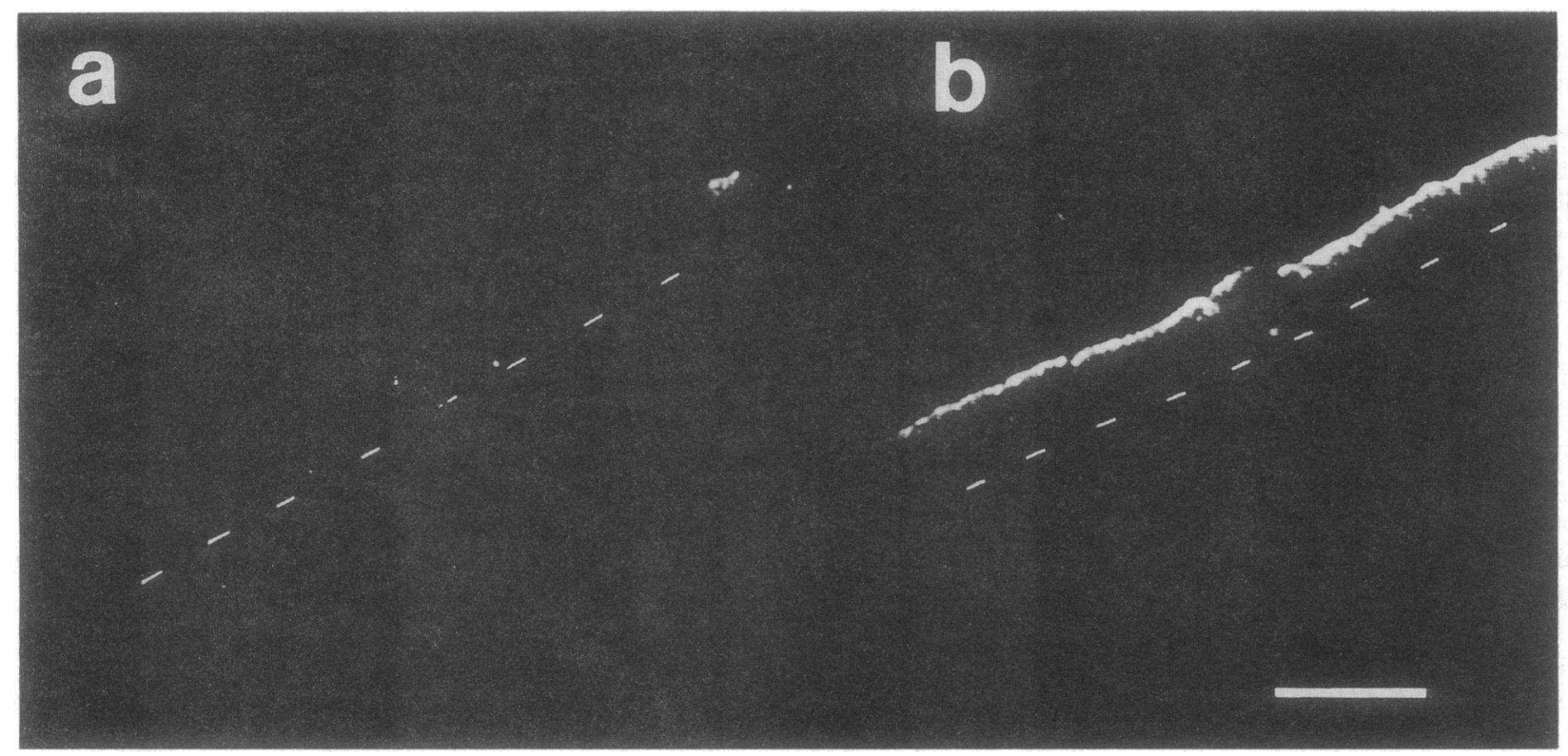

Figure 9. Immunofluorescence staining of paraffin sections with antibodies against CFTR. Monolayers of T84 cells were grown on permeable filter supports and embedded in paraffin. Sections were stained with purified mouse IgG (a) or a pool of M1-4 and M13-1 (b) as described in Methods. A dotted line indicates the surface of the filter support. Bar, $50 \mu \mathrm{m}$. 

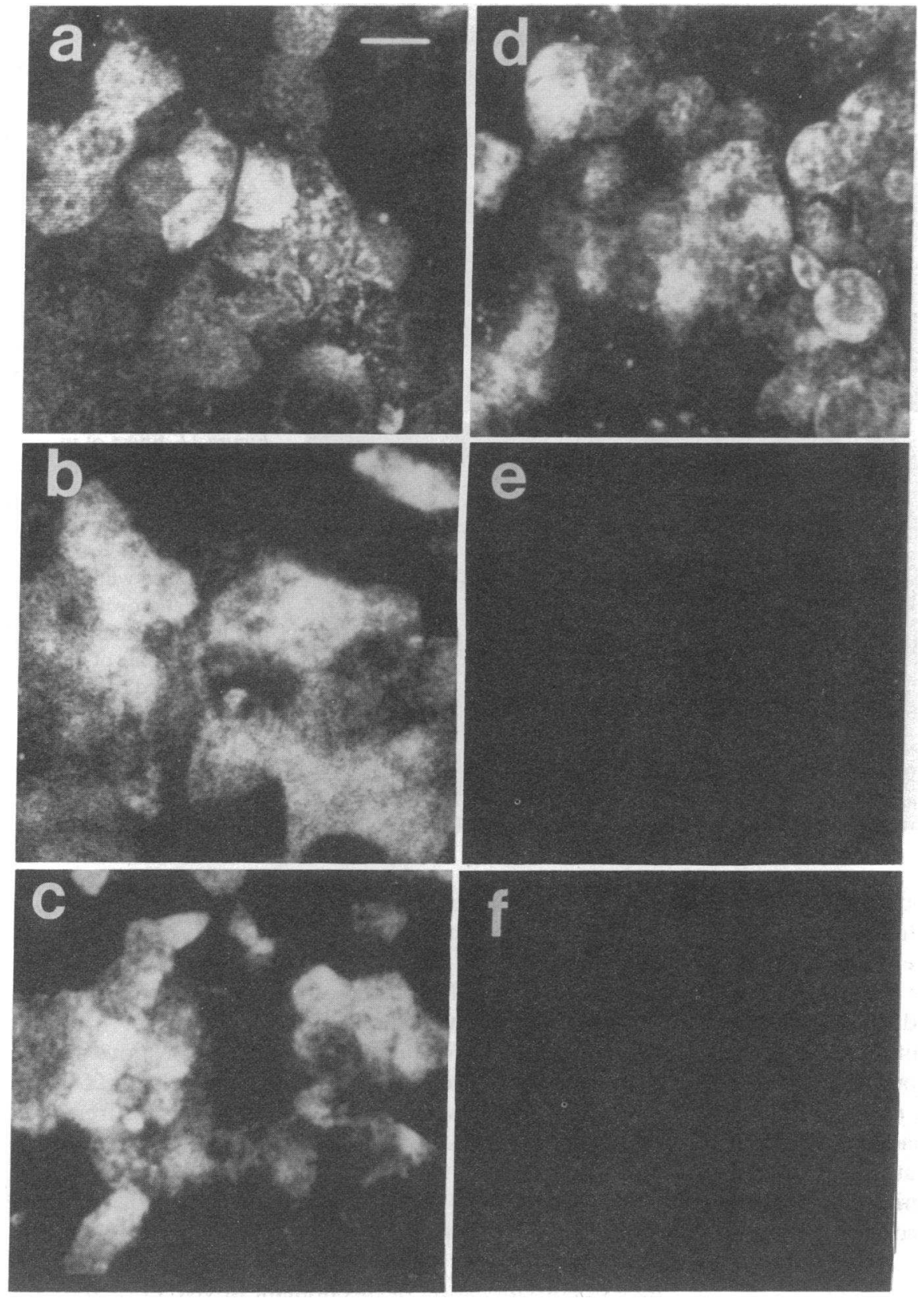

Figure 10. Localization and topology of CFTR in the apical membrane of T84 cells. Cells were prepared for staining either with $(a-c)$ or without $(d-f)$ detergent permeabilization $(0.2 \%$ Triton X-100). Monolayers were then stained with M6-4 $(a, d)$, an antibody against a predicted extracellular loop of CFTR, or with M13-1 $(b, e)$ and M1-4 $(c, f)$, antibodies against predicted intracellular domains. Bars, $10 \mu \mathrm{m}$.

$\mathrm{Cl}^{-}$conductance. At a temperature of $4-5^{\circ} \mathrm{C}$, vesicle insertion should be substantially reduced or absent; numerous studies have documented this phenomenon in a wide variety of cell systems, and reduced temperature is commonly used to block exocytosis and/or endocytosis. However, at a temperature of $4-5^{\circ} \mathrm{C}$ the cAMP-dependent protein kinase retains significant activity (see Methods). Thus, if $\mathrm{Cl}^{-}$channels are in the apical membrane, then cAMP should stimulate apical $\mathrm{Cl}^{-}$conductance at both 37 and $5^{\circ} \mathrm{C}$. On the other hand, if vesicle fusion is required, then no stimulation in $\mathrm{Cl}^{-}$conductance should be observed at the lower temperature. Although opening of apical $\mathrm{Cl}^{-}$channels might be the same at the two temperatures, the flow of $\mathrm{Cl}^{-}$through open $\mathrm{Cl}^{-}$channels may not be. In fact, the flow of $\mathrm{Cl}^{-}$should be substantially lower at $5^{\circ} \mathrm{C}$ due to the reduced mobility of $\mathrm{Cl}^{-}$at lower temperatures; the limiting equivalent conductivity of $\mathrm{Cl}^{-}$in water at $5^{\circ} \mathrm{C}$ is $49 \%$ that at $37^{\circ} \mathrm{C}(22)$. Therefore, the experimental protocol was designed to allow for possible changes in ion conductivity at the two temperatures.

For these experiments, we first eliminated the electrical resistance of the basolateral membrane (and thereby the requirement for basolateral transporters and energy-dependent processes) by adding Staphylococcus aureus $\alpha$-toxin, and then we measured the cAMP-stimulated increase in $\mathrm{Cl}^{-}$current in the presence of a $\mathrm{Cl}^{-}$concentration gradient. Each group of monolayers was studied during two consecutive periods in different chambers. Fig. 12 shows the change in apical $\mathrm{Cl}^{-}$conductance after stimulation by cAMP. When monolayers were incubated at $37^{\circ} \mathrm{C}$ and then moved to chambers at $37^{\circ} \mathrm{C}$ (still in the presence of cAMP), we measured a cAMP-stimulated $\mathrm{Cl}^{-}$current (the first bar in Fig. 12). This result suggests that cAMP activated apical $\mathrm{Cl}^{-}$channels, consistent with previous observations. When monolayers were initially stimulated at $5^{\circ} \mathrm{C}$ and then moved to $37^{\circ} \mathrm{C}$ (second bar), the cAMP-regulated current 

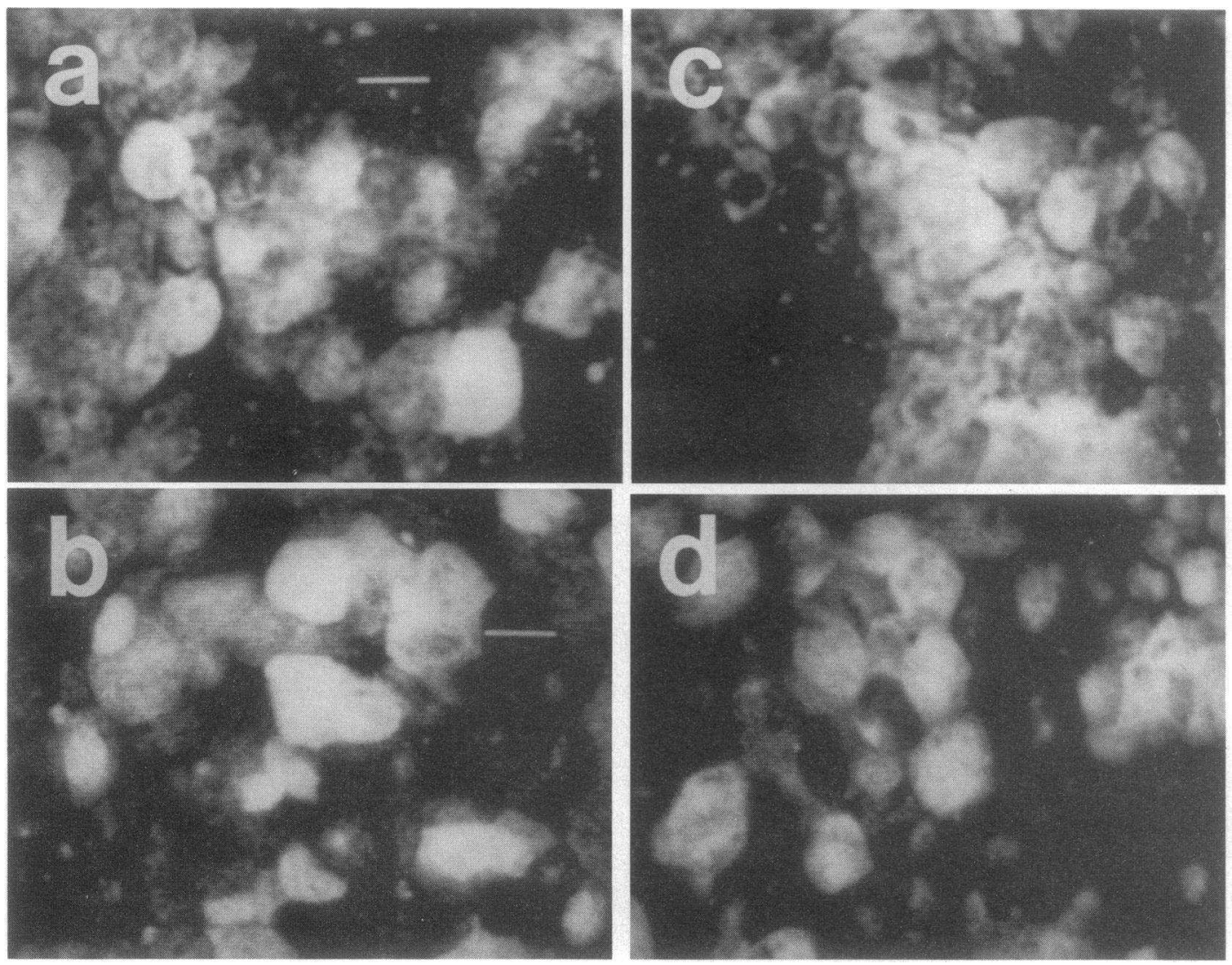

Figure 11. Effect of increasing cAMP on the distribution of CFTR in T84 cells. Cells were stained for CFTR either with $(c, d)$ or without $(a$, b) stimulation with 10 $\mu \mathrm{M}$ forskolin and $100 \mu \mathrm{M}$ IBMX. Staining of nonpermeabilized monolayers with M6-4 $(a, c)$ and of permeabilized monolayers with M13-1 $(b, d)$ are shown. Bars, $10 \mu \mathrm{m}$.

was the same as that in monolayers always incubated at $37^{\circ} \mathrm{C}$, suggesting that incubation at low temperature did not adversely affect the cells. When monolayers were stimulated at $37^{\circ} \mathrm{C}$ and then moved to $5^{\circ} \mathrm{C}$ (third bar) the $\mathrm{Cl}^{-}$current was $36 \%$ of the value observed at $37^{\circ} \mathrm{C}$. This reduction probably reflects the decrease in the rate of $\mathrm{Cl}^{-}$mobility through open $\mathrm{Cl}^{-}$channels (22). The important point is shown in the fourth bar: although current changes were slower, monolayers that were incubated at $5^{\circ} \mathrm{C}$ during both periods had as large a final current response to cAMP as monolayers that were first incubated at $37^{\circ} \mathrm{C}$ and then moved to $5^{\circ} \mathrm{C}$. Assuming that incubating at $4-5^{\circ} \mathrm{C}$ markedly reduces the rate of vesicle insertion, this

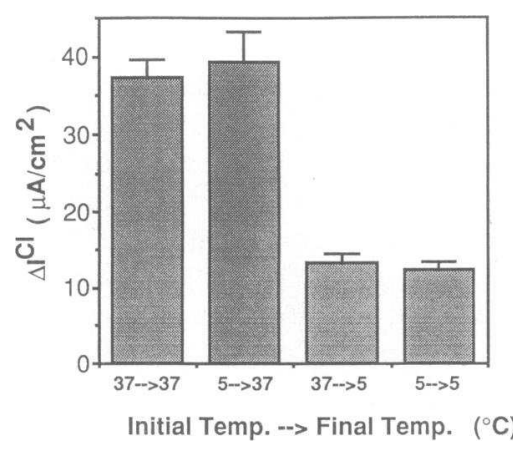

Figure 12. Effect of temperature on the response of apical $\mathrm{Cl}^{-}$ channels to cAMP. The basolateral membrane of T84 cells was permeabilized with Staphylococcus aureus $\alpha$-toxin and each monolayer was studied during two consecutive periods. During the first period, the monolayer was exposed to solution at ei-

ther 37 or $5^{\circ} \mathrm{C} .10 \mu \mathrm{M}$ cAMP was added to the submucosal solution and $50 \mathrm{~min}$ later the monolayer was moved to a second chamber and solutions were maintained at either 37 or $5^{\circ} \mathrm{C}$ in the continued presence of cAMP. Values are mean \pm SEM for the cAMP-induced change in $\mathrm{Cl}^{-}$current measured 60 min after the start of the second period. Results are from five groups of four paired monolayers. result indicates that cAMP activates $\mathrm{Cl}^{-}$channels that are already in the apical membrane where they can mediate transepithelial $\mathrm{Cl}^{-}$transport. This result is consistent with our immuno-cytochemical demonstration that CFTR is in the apical membrane in unstimulated cells.

Topology of CFTR. Our results, along with previous observations, allow several conclusions about the topology of CFTR (Fig. 13) and verify several predictions that were made from the primary sequence (2). First, M13-1 stains only permeabilized cells, which suggests that the $\mathrm{R}$ domain is intracellular. The intracellular location of the $\mathrm{R}$ domain is consistent with the finding that increased intracellular cAMP (presumably via phosphorylation by cAMP-dependent protein kinase) increases phosphorylation of this domain in vivo (23). Second, M1-4 stained only permeabilized cells, which suggests that the $\mathrm{COOH}$ terminus is also intracellular. Third, M6-4 stained nonpermeabilized cells, which suggests that the protein sequence from amino acid 107 to 118 is extracellular. Because of this observation and the prediction that the $\mathrm{NH}_{2}$ terminus is intracellular (due to the lack of a signal sequence) (2), it seems likely that the first sequence predicted by hydropathy analysis to span the bilayer in fact does so. Our finding that mutations of an amino acid in that sequence (lys 95) change the anion selectivity (8) also supports that conclusion. Fourth, identification of the glycosylated amino acids (asparagines 894 and 900) in CFTR (17) identifies an extracellular domain. These results suggest that the predicted seventh membrane-spanning sequence spans the bilayer because it lies between the intracellular $\mathbf{R}$ domain and the extracellular glycosylation site. Finally, our finding that a mutation of an amino acid in the predicted sixth membrane-spanning sequence (lys 335) changes anion selectivity of the CFTR $\mathrm{Cl}^{-}$channel (8) suggests that that sequence also spans the bilayer. 


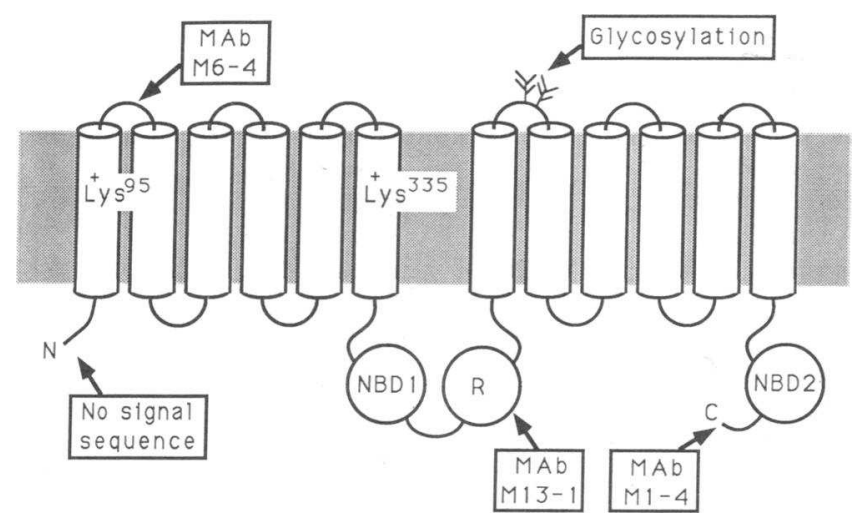

Figure 13. Model showing predicted topology of CFTR in the membrane. NBD1 and NBD2 refer to nucleotide binding domains; $\mathbf{R}$ refers to the $\mathbf{R}$ (regulatory) domain. Positions of lysine 95 and lysine 335 are indicated. Epitopes recognized by antibodies, and glycosylation site (asparagines 894 and 900) are indicated.

Conclusions. Our data demonstrate that CFTR is located in the apical membrane of three different $\mathrm{Cl}^{-}$-secreting epithelial cell lines. They also suggest that cAMP stimulates an increase in $\mathrm{Cl}^{-}$permeability of the apical membrane directly through activation of existing channels, rather than indirectly through insertion of CFTR-containing or $\mathrm{Cl}^{-}$channel-containing vesicles into the membrane. These observations, together with the recent demonstrations that CFTR forms cAMP-regulated $\mathrm{Cl}^{-}$ channels (6-8), indicate that CFTR is located in these cells where it can directly mediate transepithelial $\mathrm{Cl}^{-}$secretion.

\section{Acknowledgments}

We gratefully acknowledge the many contributions of Aurita Puga, who performed much of the specimen preparation, and Dana Ries, who helped with the antibody development and immunoprecipitation. HT29 clone 19A cells were a generous gift of Dr. Christian Laboisse. We thank the University of Iowa Hybridoma Core Facility for technical assistance in antibody generation.

This work was supported in part by the National Heart Lung and Blood Institute (HL-42385) and the National Cystic Fibrosis Foundation.

\section{References}

1. Boat, T. F., M. J. Welsh, and A. L. Beaudet. 1989. Cystic Fibrosis. In The Metabolic Basis of Inherited Disease. C. R. Scriver, A. L. Beaudet, W. S. Sly, and D. Valle, editors. McGraw-Hill, Inc., New York. 2649-2680.

2. Riordan, J. R., J. M. Rommens, B. Kerem, N. Alon, R. Rozmahel, Z. Grzelczak, J. Zielenski, S. Lok, N. Plavsic, and J. L. Chou. 1989. Identification of the cystic fibrosis gene: cloning and characterization of complementary DNA. Science (Wash. DC). 245:1066-1073.

3. Rich, D. P., M. P. Anderson, R. J. Gregory, S. H. Cheng, S. Paul, D. M. Jefferson, J. D. McCann, K. W. Klinger, A. E. Smith, and M. J. Welsh. 1990.
Expression of cystic fibrosis transmembrane conductance regulator corrects defective chloride channel regulation in cystic fibrosis airway epithelial cells. Nature (Lond.). 347:358-363.

4. Drumm, M. L., H. A. Pope, W. H. Cliff, J. M. Rommens, S. A. Marvin, L.-C. Tsui, F. C. Collins, R. A. Frizzell, and J. M. Wilson. 1990. Correction of the cystic fibrosis defect in vitro by retrovirus-mediated gene transfer. Cell. 62:12271233.

5. Quinton, P. M. 1990. Cystic fibrosis: a disease in electrolyte transport. FASEB (Fed. Am. Soc. Exp. Biol.) J. 4:2709-2717.

6. Anderson, M. P., D. R. Rich, R. J. Gregory, A. E. Smith, and M. J. Welsh 1991. Generation of cAMP-activated chloride currents by expression of CFTR. Science (Wash. DC). 251:679-682.

7. Kartner, N., J. W. Hanrahan, T. J. Jensen, A. L. Naismith, S. Sun, C. A. Ackerley, E. F. Reyes, L.-C. Tsui, J. M. Rommens, C. E. Bear, and J. R. Riordan. 1991. Expression of the cystic fibrosis gene in non-epithelial invertebrate cells produces a regulated anion conductance. Cell. 64:681-691.

8. Anderson, M. P., R. J. Gregory, S. Thompson, D. W. Souza, S. Paul, R. C. Mulligan, A. E. Smith, and M. J. Welsh. 1991. Demonstration that CFTR is a chloride channel by alteration of its anion selectivity. Science (Wash. DC). 253:202-205.

9. Madara, J. L., J. Stafford, K. Dharmsathaphorn, and S. Carlson. 1987. Structural analysis of a human intestinal epithelial cell line. Gastroenterology. 92:1133-1145.

10. Grasset, E., J. Bernabeu, and M. Pinto. 1985. Epithelial properties of human colonic carcinoma cell line Caco-2: effect of secretagogues. Am. J. Physiol. 248:C410-C418.

11. Augeron, G., and C. L. Laboisse. 1984. Emergence of permanently differentiated cell clones in a human colonic cancer cell line after treatment with sodium butyrate. Cancer Res. 44:3961-3969.

12. Fuerst, T. R., E. G. Niles, E. G. Studier, and B. Moss. 1986. Eukaryotic transient-expression system based on recombinant vaccinia virus that synthesizes bacteriophage T7 RNA polymerase. Proc. Natl. Acad. Sci. USA. 83:8122-8126.

13. Gregory, R. J., S. H. Cheng, D. R. Rich, J. Marshall, S. Paul, K. Hehir, L. Ostedgaard, K. W. Klinger, M. J. Welsh, and A. E. Smith. 1990. Expression and characterization of the cystic fibrosis transmembrane conductance regulator. $\mathrm{Na}$ ture (Lond.). 347:382-386.

14. Ostedgaard, L. S., D. M. Shasby, and M. J. Welsh. 1991. Staphylococcus aureus alpha toxin permeabilizes the basolateral membrane of a $\mathrm{Cl}^{-}$secreting epithelium. Am. J. Physiol. In press.

15. Fussle, R., S. Bhakdi, A. Sziegoleit, J. Tranum-Jensen, T. Kranz, and H.-J. Wellensiek. 1981. On the mechanism of membrane damage by Staphylococcus aureus $\alpha$-toxin. J. Cell Biol. 92:83-94.

16. Carson, M. R., S. S. Shasby, and D. M. Shasby. 1989. Histamine and inositol phosphate accumulation in endothelium: cAMP and a G protein. Am. J. Physiol. 257:L259-L264.

17. Cheng, S. H., R. J. Gregory, J. Marshall, S. Paul, D. W. Souza, G. A. White, C. R. O'Riordan, and A. E. Smith. 1990. Defective intracellular transport and processing of CFTR is the molecular basis of most cystic fibrosis. Cell. 63:827-834.

18. Anderson, M. P., and M. J. Welsh. 1991. Calcium and cAMP activate different chloride channels in the apical membrane of normal and cystic fibrosis epithelia. Proc. Natl. Acad. Sci. USA. 88:6003-6007.

19. Frizzell, R. A., and W. Cliff. 1991. Back to the chloride channel. Nature (Lond.). 350:277-278.

20. Brown, D. 1989. Vesicle recycling and cell-specific function in kidney epithelial cells. In Annual Review of Physiology. J. F. Hoffman and P. DeWeer, editors. Annual Review Inc., Palo Alto. 771-784.

21. Bae, H.-R., and A. S. Verkman. 1990. Protein kinase A regulates chloride conductance in endocytic vesicles from proximal tubule. Nature (Lond.). 348:637-639.

22. Robinson, R. A., and R. H. Stokes. 1970. Electrolyte Solutions. Butterworths Scientific Publications, London. 454 pp.

23. Cheng, S. H., D. P. Rich, J. Marshall, R. J. Gregory, M. J. Welsh, and A. E. Smith. 1991. Phosphorylation of the $R$ domain by cAMP-dependent protein kinase regulates the CFTR chloride channel. Cell. 66:1027-1036. 